\title{
Reattachment of maxillary permanent teeth fragments: a conservative approach
}

\author{
Vishal Khandelwal, ${ }^{1}$ Prathibha Anand Nayak, ${ }^{2}$ Ullal Anand Nayak, ${ }^{3}$ Nupur Ninawe ${ }^{4}$
}

${ }^{1}$ Department of Pedodontics \& Preventive Dentistry, Modern Dental College and Research Center, Indore, Madhya Pradesh, India ${ }^{2}$ Department of Periodontics, Mahatma Gandhi Dental College \& Hospital, Jaipur, Rajasthan, India

${ }^{3}$ Department of Pedodontics \& Preventive Dentistry, Mahatma Gandhi Dental College \& Hospital, Jaipur, Rajasthan, India

${ }^{4}$ Department of Pedodontics \& Preventive Dentistry, VSPM Dental College, Nagpur, Maharashtra, India

\section{Correspondence to} Dr Prathibha Anand Nayak, drprathibha_an@yahoo.co.in
To cite: Khandelwal $\mathrm{V}$ Nayak PA, Nayak UA, et al. BMJ Case Rep Published online: [please include Day Month Year] doi:10.1136/ bcr-2013-009833

\section{DESCRIPTION}

The maxillary central incisors are the teeth most susceptible to fractures caused by direct trauma due to contact sports, road accidents and falls. Aesthetic rehabilitation of crown fractures of the maxillary anterior teeth is one of the greatest challenges to the dentist. One of the options for managing coronal tooth fractures when the tooth fragment is made available by the patient and there is no or minimal violation of the biological width, is the reattachment of the dental fragment. ${ }^{1}$ Reattachment of fractured tooth fragments can provide good and long-lasting aesthetics because the tooth's original anatomic form, colour and surface texture are maintained. It also restores function, provides a positive psychological response and is a relatively simple procedure. ${ }^{1}$

A 8-year-old female patient reported to our dental clinic with trauma to maxillary central incisors. Trauma had occurred $30 \mathrm{~min}$ earlier while playing in the ground. The patient's mother had brought the fractured tooth fragment with her. Examination revealed that the tooth had a horizontal fracture involving enamel and dentin (figures 1 and 2). The fractured portion of the tooth was intact without any loss of tooth structure (figures 3 and 4). The tooth tested positive to heat and cold vitality tests. No mobility of the injured tooth was recorded and surrounding soft tissues were healthy. The tooth fragment was immediately maintained in normal saline during the period prior to restoration. Following a detailed examination, the adaptation of the fragment was checked. The appropriate matching shade of the restorative composite resin was selected. After isolation of the fractured tooth, $45^{\circ}$ of bevel was given to the fractured margins of the tooth and fragment. Acid etching of both the remaining tooth surface and the fragment were carried out for $15 \mathrm{~s}$ using $37 \%$ phosphoric acid (Scotchbond, Etchant Phosphoric Acid from 3M ESPE) then rinsed thoroughly with water and air

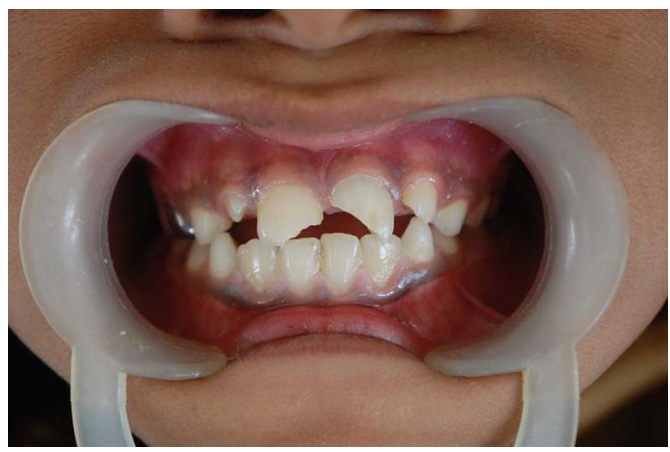

Figure 1 Preoperative photograph showing fractured $11,21$.

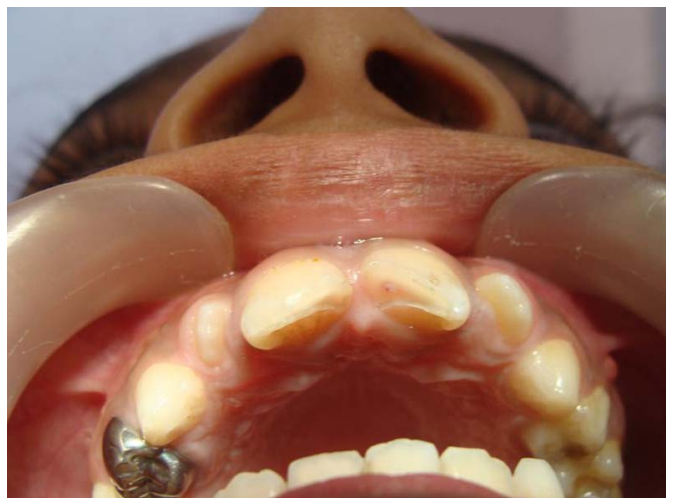

Figure 2 Preoperative photograph showing fractured 11, 21 (occlusal view).

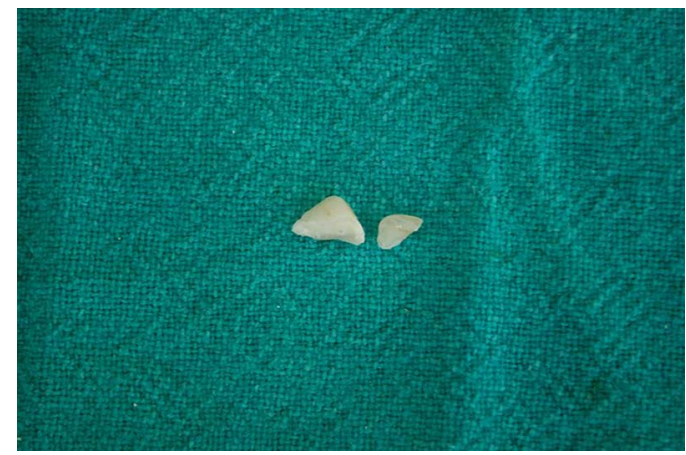

Figure 3 Fractured fragments.

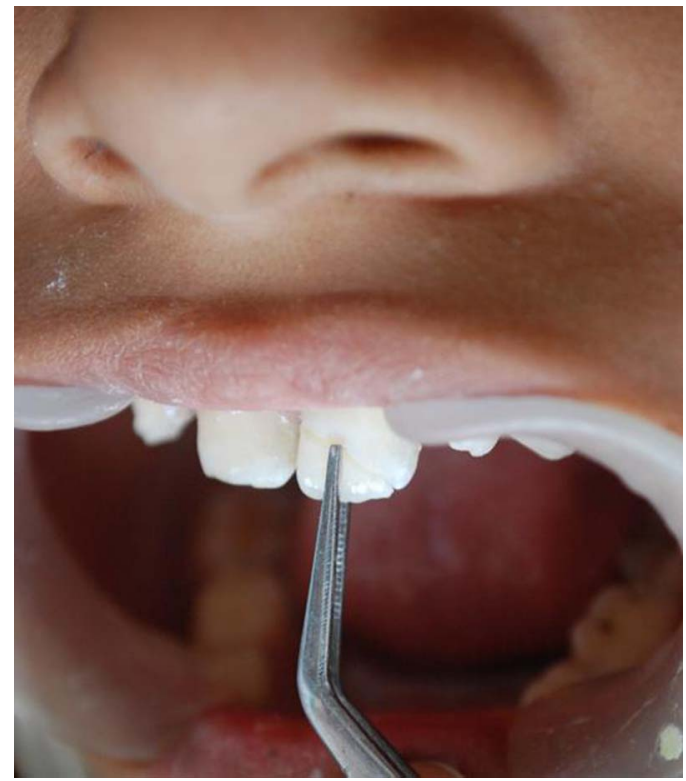

Figure 4 Fractured segment tried on the tooth before attachment. 


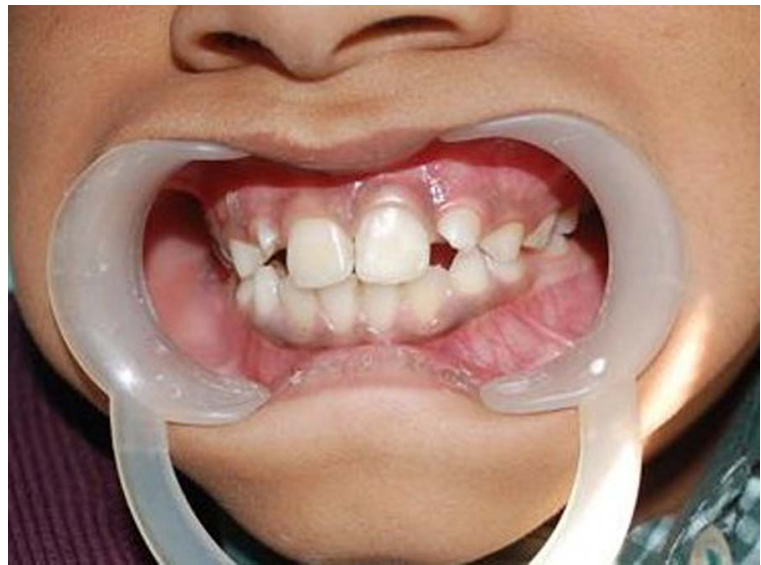

Figure 5 Postoperative restored teeth.

dried. The bonding agent (Scotchbond, 3M ESPE, St Paul, Minnesota, USA) was applied on the etched surfaces and light cured using visible light. Then the selected shade of composite resin (Esthet XD, Denstply) was applied on the fragment and tooth surface. The restoration was light-cured for $40 \mathrm{~s}$, finished and polished (Sof-Lex disks 3M ESPE, St Paul, Minnesota, USA) (figure 5). The patient was satisfied with the aesthetics achieved.

\section{Learning points}

- The aesthetic is excellent as it has the advantage of original tooth's shape, colour, translucence and surface structure.

- It is easy to practice and economical method that has the potential to assume the incisal strength during tooth functioning.

- This is a minimally invasive restorative procedure. The method ensures increased wearing steadiness and thus creates better function.

- Patient cooperation and understanding of the limitations of the treatment is of utmost importance for good prognosis.

Competing interests None.

Patient consent Obtained.

Provenance and peer review Not commissioned; externally peer reviewed.

\section{REFERENCE}

1 Macedo GV, Diaz PI, de O'Fernandes CA, et al. Reattachment of anterior teeth fragments: a conservative approach. J Esthet Restor Dent 2008;20:5-20.

Copyright 2013 BMJ Publishing Group. All rights reserved. For permission to reuse any of this content visit http://group.bmj.com/group/rights-licensing/permissions.

BMJ Case Report Fellows may re-use this article for personal use and teaching without any further permission.

Become a Fellow of BMJ Case Reports today and you can:

- Submit as many cases as you like

- Enjoy fast sympathetic peer review and rapid publication of accepted articles

- Access all the published articles

- Re-use any of the published material for personal use and teaching without further permission

For information on Institutional Fellowships contact consortiasales@bmjgroup.com

Visit casereports.bmj.com for more articles like this and to become a Fellow 